\title{
RICINOLEIC ACID METHYL ESTER (RAME): SYNTHESIS, CHARACTERIZATION AND DETERMINATION OF OPTIMUM PROCESS PARAMETERS
}

\section{Mohammed Awwalu USMAN ${ }^{1, *}$, Rasheed Uthman OWOLABI, Emmanuel Nwannebuke ONOH}

\author{
${ }^{1}$ Department of Chemical and Petroleum Engineering, University of Lagos, Akoka, Yaba, Lagos 101017, Nigeria
}

\begin{abstract}
Castor oil is a unique vegetable oil with peculiar features such as extremely high viscosity and unusual miscibility with short chain alcohol. This necessitates a comprehensive exploration of all process parameters in the transesterification of castor oil, which is rarely done for other vegetable oils. In this study, the methanolysis of castor oil using alkaline catalyst (potassium hydroxide, $\mathrm{KOH}$ ) was investigated in a batch reactor via the conventional one-variable-at-a-time protocol. The effects of process parameters including reaction time, reaction temperature, methanol-to-oil molar ratio, catalyst concentration and stirring rate on biodiesel yield were evaluated. The results indicate the significant influence of all parameters on the biodiesel yield. An optimum yield of $96 \%$ was achieved at a reaction time of $60 \mathrm{~min}$, reaction temperature of $65^{\circ} \mathrm{C}$, methanol-to-oil molar ratio of 12:1, catalyst concentration of $1.5 \% \mathrm{w} / \mathrm{w}$ and stirring rate of $125 \mathrm{rpm}$. The fuel properties and fourier transform infra-red (FTIR) spectrum of the biodiesel obtained at optimum condition were mostly found to be in conformity with the ASTM D6751 and EN 14214 specification standards.
\end{abstract}

Keywords: Castor oil, Methanolysis, Ricinoleic acid methyl ester (RAME), Process parameters, Fuel properties

\section{INTRODUCTION}

World growth in population, industrialization, and economy has occasioned exponential increase in the global energy demand [1]. On the other hand, the depletion of fossil fuel resources and climate change have heightened search for renewable and environmentally benign fuel sources to meet this ever increasing energy demand. The transport sector, which depend heavily on oil-derived liquid products such as gasoline and diesel, globally occupies the $3^{\text {rd }}$ place in terms of total energy consumption and greenhouse gas (GHG) emission (behind the industry and building sectors) [2]. Biodiesel is one of the sustainable sources of energy for meeting soaring global transport energy demand and lowering GHG emissions significantly. Non-edible plant oils are considered as very suitable candidates for biodiesel production because they can be grown in harsh and marginal lands which requires less maintenance, less soil fertility and less water as opposed to arable lands for growing edible vegetable oils [2].

Castor (Ricinus communis L.) is an important non-edible industrial oilseed crop grown in tropical, subtropical and temperate regions across the world. In 2012, castor was reported to have been cultivated in a total of 1.5 million hectares with an average production of 1.5 million tons and productivity of 995 $\mathrm{kg} / \mathrm{ha}$, with India, Brazil, Russia and China being the major producing countries of the world [3]. Though, Nigeria is currently trailing behind these major oil producing countries, Ibeagha and Onwualu [4] opined that castor can attract up to 25 billion naira $(105,488,032$ million dollars) to the Nigerian economy. Concerted effort is being made to realize this potential within the broader context of economic diversification through agriculture. On the average, castor seeds contain about $46-55 \%$ oil by weight, with ricinoleic acid accounting for $80-90 \%$ of its fatty acid composition [5,6]. The occurrence of both double bond and a hydroxyl group on ricinoleic acid confer on castor oil the unique features of extremely high viscosity and miscibility in all proportion with short chain alcohol [5]. 
Castor oil is therefore a unique candidate for biodiesel production which requires thorough and comprehensive study.

There are five process parameters that influence the transesterification reaction of vegetable oil, namely reaction temperature, reaction time, alcohol/oil molar ratio, catalyst loading, and stirring rate. For a given alcohol and catalyst type, most studies on tranesterification of vegetable oils explore limited variables while taking others for granted. While this may suffice for other vegetable oils, it is not adequate in the case of castor oil because of its unique features. Most of the previous studies on castor oil tranesterification have however followed this trend of selective parametric study.

Meneghetti et al. [7] investigated the ethanolysis and methanolysis of castor oil in the presence of several classical catalytic systems. They evaluated the effect of reaction time and nature of catalyst on biodiesel yield. It was concluded that though biodiesel can be produced via either ethanolysis or methanolysis, the latter was much more rapid. Verma and Madras [8] investigated biodiesel synthesis from castor oil via methanolysis and ethanolysis at subcritical and supercritical conditions. The effects of molar ratio of alcohol to oil, temperature and time on biodiesel yield were evaluated. Pena et al. [9] studied the effect of catalyst type $\left(\mathrm{CH}_{3} \mathrm{OK}, \mathrm{NaOH}, \mathrm{KOH}\right)$, reaction time and co-solvent (hexane) on biodiesel yield in the methanolysis of castor oil. The result indicates the positive impact of co-solvent and superiority of the methoxide catalyst. Sousa et al. [10] studied the production of methyl esters from castor oil via methanolysis after neutralization of the oil with glycerol. Reaction time was the only process variable evaluated in addition to the effect of neutralization. Feng et al. [11] carried out the methanolysis of castor oil catalyzed by novel basic ionic liquid, [BTBD]OH. The effects of reaction time, reaction temperature and catalyst loading on biodiesel yield were evaluated. Negm et al. [12] synthesized biodiesel from Egyptian castor oil via the conventional base catalyzed methanolysis. They evaluated the physico-chemical properties of the obtained biodiesel and compared same with those of several biodiesels from different vegetable oil. No process variable was evaluated in this study.

Considering this few reviews, it is apparent that there is paucity of comprehensive study on transesterification of castor oil that explores all five process variables. The only exception, to the best of our knowledge, is the work of Silitonga et al. [13] where all five variables were investigated. However, they employed the method of esterification-neutralization-transesterification in the processing of the castor oil rather than the conventional direct transesterification. It is equally evident, even from the tranesterification of other vegetable oils, that these variables show significant effect on both the yield and fuel properties of the obtained biodiesel. This work therefore aims to investigate the influence of all five process parameters on the biodiesel yield synthesized from methanolysis of castor oil thereby bridging existing gap. Also the fuel properties and characterization of the biodiesel obtained at optimal condition was carried out to assess compliance with the specifications of the American testing standards (ASTM D6751) and European standards (EN 14214).

\section{MATERIAL AND METHOD}

\subsection{Material}

Refined castor oil was purchased from Hollyland Chemicals Ltd, Ojota, Lagos state, Nigeria (Latitude 6.5833 and Longitude 3.75). It is a characteristically brownish viscous liquid packaged in 6-liter white plastic bottle. Analytical grade methanol (99.5\%) packed in amber colour bottled was purchased from Evans Chemicals Ltd, Ilasamaja, Lagos, Nigeria. $\mathrm{KOH}$ was provided by the management of Chemical Engineering Petroleum Laboratory II of the University of Lagos, Nigeria. All reagents were analytical grade and were used without purification. The physico-chemical properties of castor oil were determined using standard methods [14] and presented in Table 1. 
Table 1. Physico-chemical analysis of castor oil

\begin{tabular}{|l|l|}
\hline Properties & Value Obtained \\
\hline Appearance & Brrownish Liquid \\
\hline Volatile matter & 2.28 \\
\hline Moisture content, $\% \mathrm{w} / \mathrm{w}$ & 0.04 \\
\hline Viscosity (kinematic) at $40^{\circ} \mathrm{C}, \mathrm{mm} / \mathrm{s}^{2}$ & 21.76 \\
\hline Acid value, $\mathrm{mgKOH} / \mathrm{g}$ & 6.74 \\
\hline Free fatty acid, $\%$ & 2.37 \\
\hline Peroxide Value, $\mathrm{mEg} / \mathrm{Kg}$ & 1.96 \\
\hline Saponification $\mathrm{Value}, \mathrm{mg} / \mathrm{KOH}$ & 200.48 \\
\hline Unsaponifiable $\mathrm{matter} \mathrm{g} / \mathrm{Kg}$ & 14.5 \\
\hline Specific gravity at $25^{\circ} \mathrm{C}$ & 0.9560 \\
\hline Iodine value, $\mathrm{g} / 100 \mathrm{~g}$ & 107.1 \\
\hline Refractive index & 1.4870 \\
\hline
\end{tabular}

The molecular weight (MW) of the oil was determined from the saponification value (SV) and acid value (AV) using Eq. $1[15,16]$.

$$
M W=\frac{56.1 \times 3 \times 1000}{S V-A V}
$$

\subsection{Methods}

\subsubsection{Transesterification and parametric study}

A known mass of castor oil (100 g) was measured into a beaker and heated mildly to evaporate any moisture present. The oil was allowed to cool while the temperature was monitored to the set reaction temperature. A determined mass of methanol and of $\mathrm{KOH}$ pellets necessary to give the desired methanol-to-oil molar ratio and catalyst concentration, respectively, were put together for dissolution. The Castor oil beaker was partially immersed in the water bath set-up (at $65^{\circ} \mathrm{C}$ reaction temperature) with magnetic stirrer set at specified rotational speed. The methanol- $\mathrm{KOH}$ mixture was introduced into the stirred castor oil immediately for a period of time. The reaction was monitored according to the following variation in reaction time 30, 45, 60, 90, 120 and 180 min, while keeping molar ratio, catalyst amount, reaction temperature and stirring rate constant. The resulting reaction mixture was allowed to cool, settle and was separated using the separation funnel. The Biodiesel (topmost layer) was separated from the glycerin (bottom layer) and the little catalyst solution mixed with soap solution (thin middle layer).The Biodiesel was washed with $2 \%$ water amount for three times to obtain purer biodiesel (RAME) and its percentage yield was determined gravimetrically using Eq. 2.

$$
\text { RAMEyield }=\frac{\text { massofRAMEproduced }}{\text { massofcastoroilcharged }} \times 100
$$

The procedure was repeated six times with varying molar ratio $(3: 1,6: 1.12: 1,15: 1,20: 1,25: 1)$ while keeping reaction time, catalyst amount, reaction temperature and stirring rate constant at 60 minutes, $1.5 \% \mathrm{w} / \mathrm{w}, 65^{\circ} \mathrm{C}$ and $250 \mathrm{rpm}$, respectively. The same procedure was repeated six times with varying catalyst amount $(0.5,1.0,1.5,2.0,2.5$ and $3.0 \% \mathrm{w} / \mathrm{w})$ while keeping molar ratio, reaction time, reaction temperature and stirring rate constant at $12: 1,60 \mathrm{~min}, 65^{\circ} \mathrm{C}$ and $250 \mathrm{rpm}$, respectively. The procedure was also repeated six times with varying reaction temperature $\left(50,60,65,70,75\right.$ and $\left.80^{\circ} \mathrm{C}\right)$ while keeping molar ratio, reaction time, catalyst amount and stirring rate constant at 12:1, 60 min, $1.5 \% \mathrm{w} / \mathrm{w}$ and $250 \mathrm{rpm}$, respectively. Lastly, the procedure was repeated six times with varying stirring rate $(100,125,250,350,400$ and $500 \mathrm{rpm})$ while keeping molar ratio, reaction time, catalyst 
amount and reaction temperature constant at $12: 1,60 \mathrm{~min}, 1.5 \% \mathrm{w} / \mathrm{w}$ and $65^{\circ} \mathrm{C}$, respectively. Since the optimum condition from each study was used in the subsequent study, the biodiesel from this last study with the highest yield represent the optimal biodiesel.

\subsubsection{Pysico-chemical properties and characterization of RAME}

The physical and chemical properties of the obtained biodiesel at optimum condition were determined according to the appropriate standard methods, namely density (EN ISO 3675: 1988), kinematic viscosity (EN ISO 3104: 2003), flash point (EN ISO 2719: 2002), iodine value (EN 14111: 2003), acid value (EN 14104: 2003) and water content (EN ISO 12937: 2000).

The composition of the RAME was analyzed by a gas chromatograph (Agilent $6890 \mathrm{~N}$ ) equipped with a flame ionization detector (FID), a 7683B auto-injector, a cool on-column injector-system and an Ultra-Alloy-HT1 column (Frontier, $10 \mathrm{~m} \times 0.53 \mathrm{~mm} \times 0.15 \mu \mathrm{m}$ ). The oven temperature was started at $70{ }^{\circ} \mathrm{C}$ for $1 \mathrm{~min}$, then increased to $160{ }^{\circ} \mathrm{C}$ at a rate of $15{ }^{\circ} \mathrm{C} / \mathrm{min}$, to $260{ }^{\circ} \mathrm{C}$ at a rate of $7{ }^{\circ} \mathrm{C} / \mathrm{min}$, to 380 ${ }^{\circ} \mathrm{C}$ at a rate of $5{ }^{\circ} \mathrm{C} / \mathrm{min}$, and held at this temperature for $5 \mathrm{~min}$. the FID temperature was set at $380{ }^{\circ} \mathrm{C}$ and the injector temperature was tracked to the column temperature. About $1 \mu \mathrm{L}$ of the sample diluted with hexane was injected into the column.

The infra-red spectrum was obtained following the procedure reported by Rabelo et al. [17]. The FTIR spectrum was recorded using Shimadzu spectrometer at ambient temperature in the wave number 4000 $400 \mathrm{~cm}^{-1}$.

\subsection{Parametric Study}

\subsubsection{Effect of reaction time}

Figure 1 illustrates the effect of reaction time on biodiesel (RAME) yield. The reaction time was varied from $45 \mathrm{~min}$ to $180 \mathrm{~min}$, while the other parameters were kept constant at molar ratio of 6:1, catalyst concentration of $1.5 \%$, reaction temperature of $65^{\circ} \mathrm{C}$ and stirring rate of $250 \mathrm{rpm}$. The RAME yield increased from $70 \%$ at $45 \mathrm{~min}$ to $80.2 \%$ at $60 \mathrm{~min}$, and thereafter decrease with time. This decrease may be attributed to the combination reaction of the biodiesel and glycerol into monoglycerides and the formation of gels [18]. Similar trend was also reported by several other researchers in the transesterification of vegetable oils [8-11, 13, 19-20].

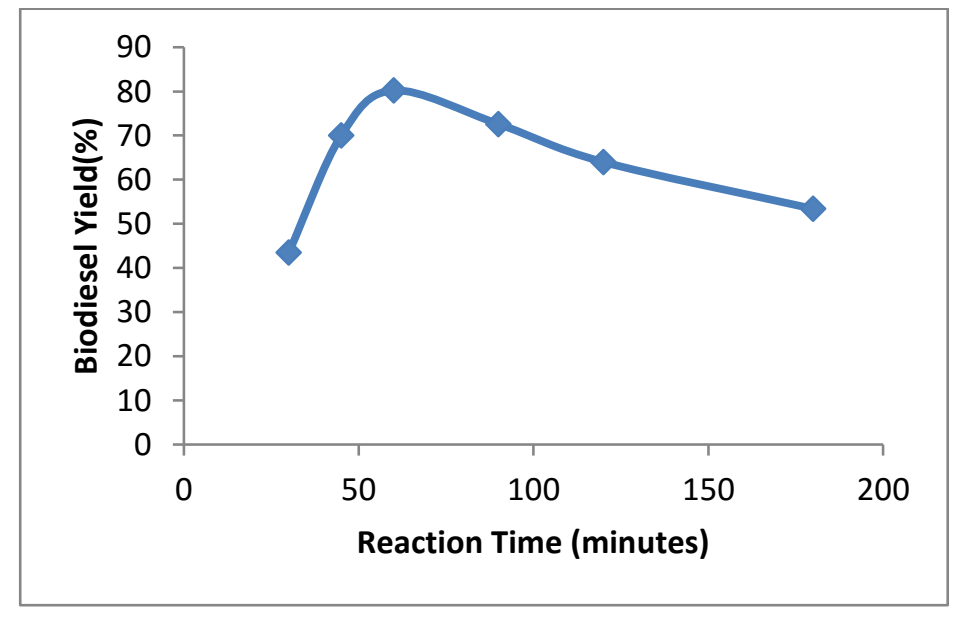

Figure 1. Effect of reaction time on biodiesel yield 


\subsubsection{Effect of methanol-to-oil malor ratio}

Figure 2 shows the effect of molar ratio of methanol to oil on the yield of RAME. The molar ratio was varied from 3:1 to 25:1 while keeping reaction time, catalyst amount, reaction temperature and stirring rate constant at $60 \mathrm{~min}, 1.5 \% \mathrm{w} / \mathrm{w}, 65^{\circ} \mathrm{C}$ and $250 \mathrm{rpm}$, respectively. Though the reaction stoichiometry indicates 3:1 molar ratio of methanol to oil for transesterification, several studies show no reasonable yield at this ratio. Transesterification being a reversible reaction requires excess methanol to drive the forward reaction to completion. A recent comprehensive review of the effect of molar ratio on the transesterification of triglycerides abundantly attests to this assertion [21]. In this study, a molar ratio of 3:1 merely produced slurry. The yield increased from $91 \%$ at molar ratio of 6:1 to $95 \%$ at a molar ratio of 12:1. Further increase in methanol to oil molar ratio result in decreasing RAME yield. Similar trend have been reported by other workers [8, 13, 19, 20, 22].

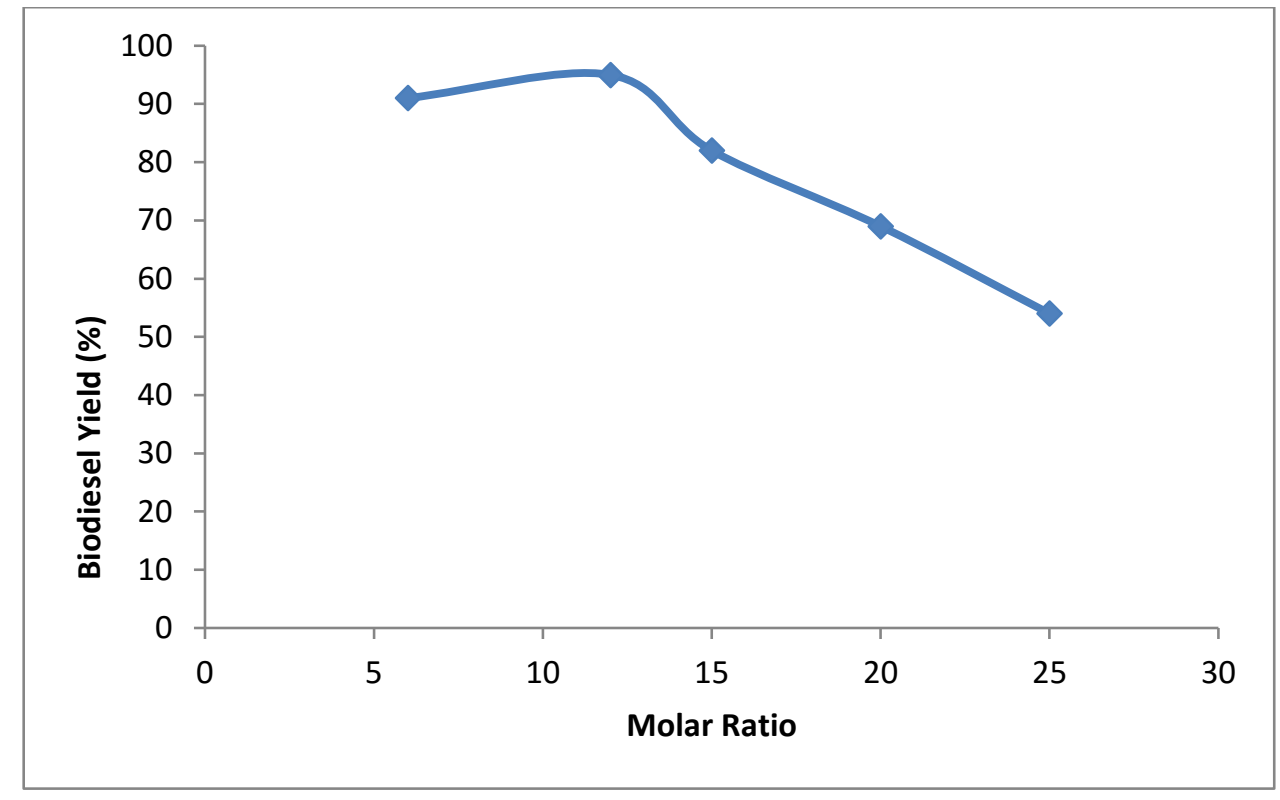

Figure 2. Effect of methanol to oil molar ratio on biodiesel yield

\subsubsection{Effect of Catalyst Concentration}

Figure 3 shows the influence of catalyst concentration on the RAME yield. The KOH concentration was varied from 1.0 to $3.0 \mathrm{wt} \%$ while keeping molar ratio, reaction time, reaction temperature and stirring rate constant at $12: 1,60 \mathrm{~min}, 65^{\circ} \mathrm{C}$ and $250 \mathrm{rpm}$, respectively. There was a sharp increase in RAME yield from $48 \%$ to $93 \%$ as the catalyst concentration increased from 1.0 to $1.5 \mathrm{wt} \%$. Subsequently, the yield decreases with further increase in $\mathrm{KOH}$ concentration. Low catalyst concentration is reported to cause low biodiesel yield due to incomplete transesterification [23] and increased acidity of triglycerides [24]. A higher $\mathrm{KOH}$ catalyst concentration may also cause low yield due to excess soap formation. Further, excess amount of alkali catalyst could result in low biodiesel yield due to the formation of emulsion and increased viscosity causing gelation [25,26]. Similar trend was reported by other studies in the transesterification of vegetable oil [8, 13, 19-20, 22]. Deligiannis et al. [27] reported that the catalyst amount of $1.5 \mathrm{wt} \%$ achieved $94.2 \%$ methyl ester yield in $\mathrm{KOH}$ methanolysis of castor oil. 


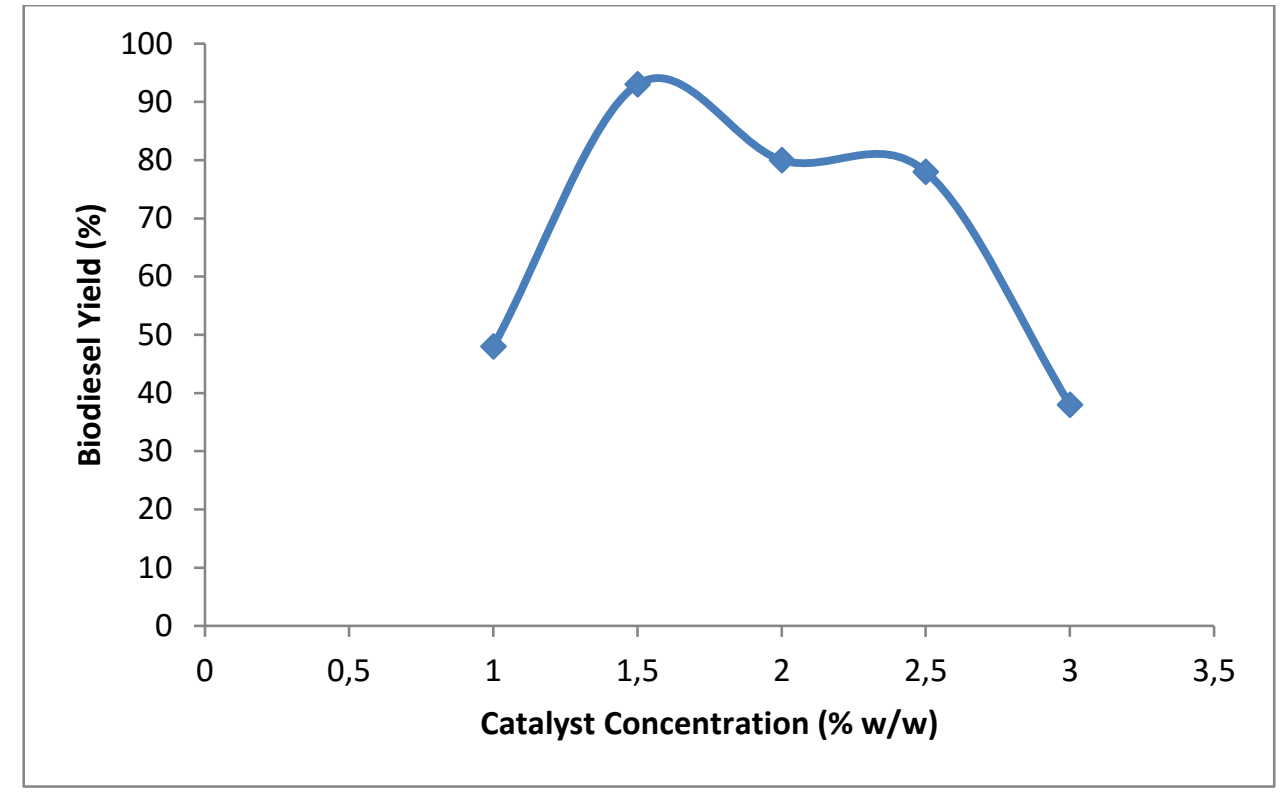

Figure 3. Effect of catalyst concentration on biodiesel yield

\subsubsection{Effect of reaction temperature}

Figure 4 illustrates the effect of reaction temperature on RAME yield. The temperature was varied from $50^{\circ} \mathrm{C}$ to $80^{\circ} \mathrm{C}$, while keeping molar ratio, reaction time, catalyst amount and stirring rate constant at 12:1, $60 \mathrm{~min}, 1.5 \% \mathrm{w} / \mathrm{w}$ and $250 \mathrm{rpm}$, respectively. An increase in yield was observed as the temperature increased from $50^{\circ} \mathrm{C}$ to $65^{\circ} \mathrm{C}$. The optimum yield of $93 \%$ was achieved at $65^{\circ} \mathrm{C}$. This may be attributed to the enhanced settlement of glycerol on account of increased temperature [13]. According to Yang et al. [22], increasing biodiesel yield with temperature may be because of the progressive intensification in molecular collision and the decrease in viscosity of castor oil as temperature increases, a situation that favours reduced mass transfer resistance and enhanced reaction rate. Further increase in temperature beyond $65^{\circ} \mathrm{C}$ result in decreased biodiesel yield. This may be due to saponification of the triglycerides before the transesterification was completed.

Similar trend have been reported by others in the transesterification of vegetable oils $[8,11,13,19-20$, 22].

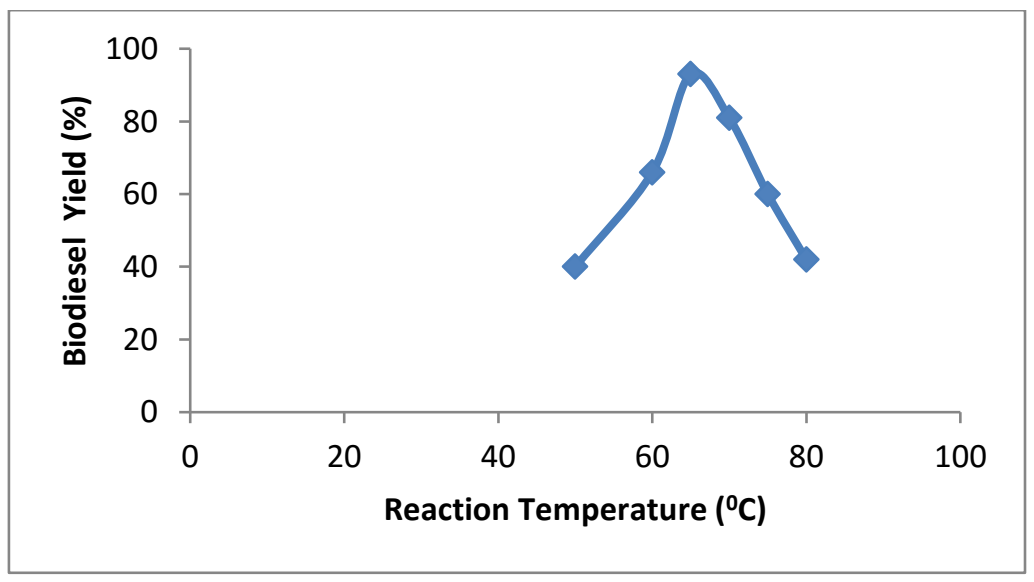

Figure 4. Effect of reaction temperature on biodiesel yield 


\subsubsection{Effect of stirring rate}

The effect of stirring rate on the biodiesel yield is illustrated in Fig. 5. The stirring rate enhances the contact of the reactants during transesterification, causing a faster reaction rate by reducing mass transfer resistance. In the absence of stirring, the transesterification reaction occurs only at the interface leading to slow reaction rate [22]. In this study, the stirring rate was varied from $100 \mathrm{rpm}$ to $500 \mathrm{rpm}$ while keeping molar ratio, reaction time, catalyst amount and reaction temperature constant at 12:1, $60 \mathrm{~min}, 1.5 \% \mathrm{w} / \mathrm{w}$ and $65^{\circ} \mathrm{C}$, respectively. As shown in Figure 5, there was an initial increase in yield from $82 \%$ to $96 \%$ as stirring rate increase from $100 \mathrm{rpm}$ to $125 \mathrm{rpm}$ and almost remain constant up to $350 \mathrm{rpm}$, subsequently there is a sharp decrease in biodiesel yield with further increase in stirring rate. Similar trend have been reported by others in the transesterification of vegetable oil $[13,20,22$, $28,29]$. Considering the higher energy consumption at high stirring rate together with biodiesel yield, a stirring rate of $125 \mathrm{rpm}$ was taken as optimum value for this study.

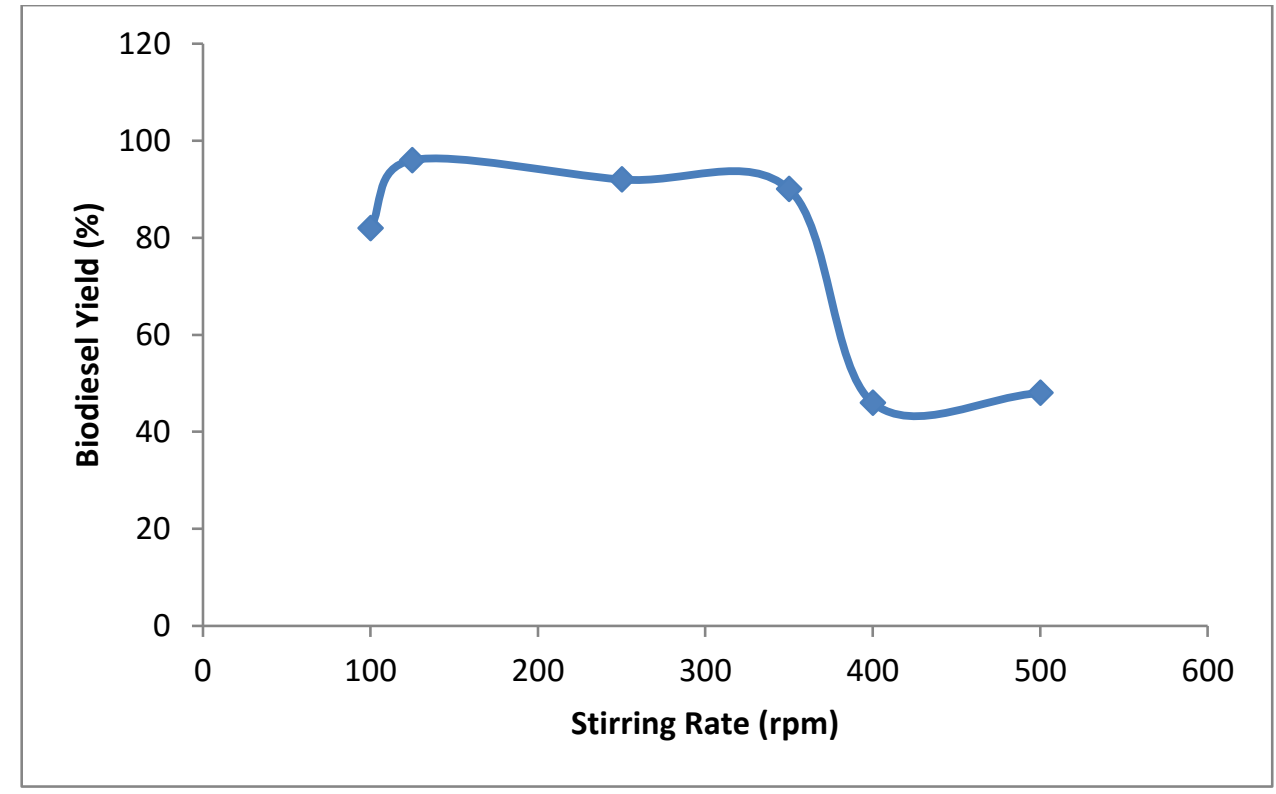

Figure 5. Effect of stirring rate on biodiesel yield

The parametric study was conducted in a sequential manner such that the local optimum variable established in an earlier study is used for the subsequent studies. Consequently, the global optimum is depicted by the study in subsection 3.1.5. The global or overall highest RAME yield was $96 \%$ achieved at the reaction time of $60 \mathrm{~min}$, methanol to oil molar ratio of 12:1, catalyst concentration of $1.5 \mathrm{wt} \%$, reaction temperature of $65^{\circ} \mathrm{C}$ and stirring rate of $125 \mathrm{rpm}$. Table 2 shows the optimum parameters for two other studies in comparison with this study for the methanolysis of castor oil using $\mathrm{KOH}$ catalyzed process. The current study is clearly superior to the work of Saez-Bastante et al. [30] both in terms of higher biodiesel yield and lower stirring rate (which translate to lower cost of production). The biodiesel yield for the work of Silitonga et al. [13] is slightly higher than that of this study, though achieved at a much higher stirring rate. This may be attributed to the processing route employed by the former, which entail esterification, neutralization and transesterifcation in a sequential manner rather than direct transesterifcation used in this study. It is pertinent to mention that the higher stirring rates in the other two studies are reflective of the much higher viscosities of the crude castor oil used. The kinematic viscosities $\left(a t 40^{\circ} \mathrm{C}\right)$ of the castor oil used in the three studies are as follows: $21.76 \mathrm{~mm}^{2} / \mathrm{s}$ (this study), $298 \mathrm{~mm}^{2} / \mathrm{s}$ [30], $236.9 \mathrm{~mm}^{2} / \mathrm{s}$ [13]. 
Table 2. Comparison of optimum parameters from various studies

\begin{tabular}{|l|l|l|l|l|l|l|}
\hline Reference & Time & Temperature & Molar ratio & Cat. Con. & Stirring rate & Biodiesel yield \\
\hline This study & $60 \mathrm{~min}$ & $65^{\circ} \mathrm{C}$ & $12: 1$ & $1.5 \mathrm{wt} \%$ & $125 \mathrm{rpm}$ & $96 \%$ \\
\hline$[30]$ & $3 \mathrm{hr}$ & $50^{\circ} \mathrm{C}$ & $9: 1$ & $1.5 \mathrm{wt} \%$ & $1100 \mathrm{rpm}$ & $54.1 \%$ \\
\hline$[13]$ & $90 \mathrm{~min}$ & $60^{\circ} \mathrm{C}$ & $9: 1$ & $0.75 \mathrm{wt} \%$ & $1000 \mathrm{rpm}$ & $98.27 \%$ \\
\hline
\end{tabular}

It is also instructive to compare the result of this study with other recent works on biodiesel production from castor oil via other methods. Dai et al. [31] obtained an optimum biodiesel conversion (or yield) of $72.2 \%$ at the reaction conditions: methanol to oil molar ratio $24: 1$, catalyst amount $6 \mathrm{wt} \%$, reaction temperature $65^{\circ} \mathrm{C}$ and reaction time $2 \mathrm{hr}$ in the methanolysis of castor oil using a highly basic solid catalyst, $\mathrm{Li}_{2} \mathrm{TiO}_{3}$. Roman-Figueroa et al. [32] investigated the production of biodiesel by non-catalytic supercritical methanolysis of crude castor oil, a maximum yield of $96.5 \%$ was obtained at $300^{\circ} \mathrm{C}(21$ $\mathrm{MPa}$ ) and 90 min using a methanol to oil molar ratio of 43:1. In comparison, it can be said that the optimum values obtained in the current study are significantly better.

\subsection{Characterization and physico-chemical properties of biodiesel}

The biodiesel obtained at optimum condition was subjected to FTIR characterization, GC-MS analysis and test of relevant fuel properties. The results of these analyses are presented and discussed in this subsection.

\subsubsection{FTIR spectra}

An FTIR spectrum of the synthesized biodiesel is shown in Figure 6. According to Rabelo et al. [17], the main spectral region enabling chemical distinction between feedstock oil and its resultant biodiesel is $1500-900 \mathrm{~cm}^{-1}$, which is referred to as 'fingerprint region'. The peak at $1464.02 \mathrm{~cm}^{-1}$ corresponds to asymmetric stretch of $-\mathrm{CH}_{3}$ while the peak at $1195.91 \mathrm{~cm}^{-1}$ corresponds to the stretching of O- $\mathrm{CH}_{3}$ [33]. The intense $\mathrm{C}=\mathrm{O}$ stretching band of methyl ester appears at $1743.71 \mathrm{~cm}^{-1}$ for the biodiesel [34].
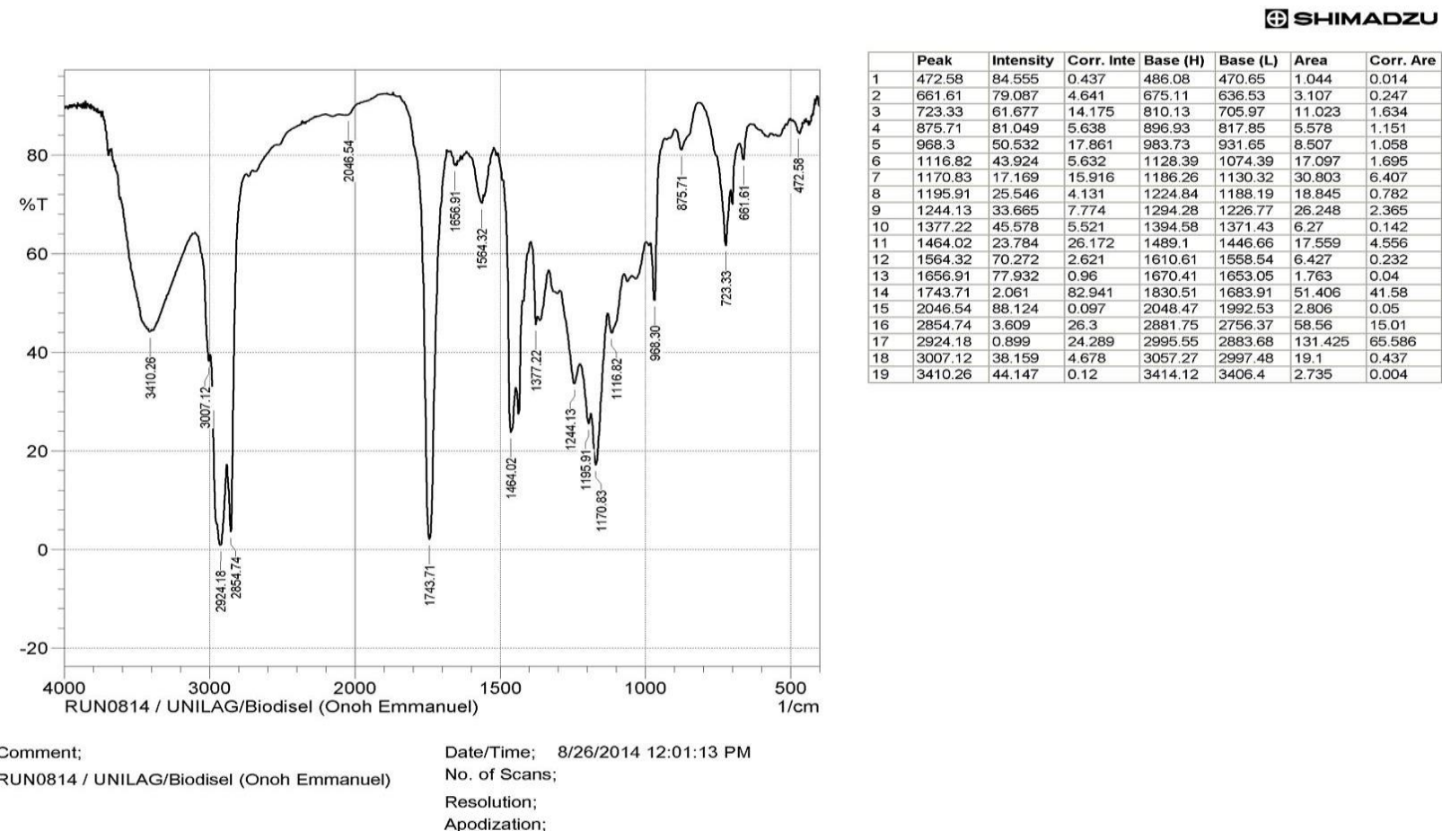

Figure 6. FTIR spectra of biodiesel (RAME) 


\subsubsection{Fatty acid methyl ester composition of biodiesel}

The physicochemical properties of biodiesel and invariably the fuel performance are a strong function of its fatty acid profile, which in turn corresponds to that of the vegetable oil feedstock [33]. The composition of biodiesel in this study as determined by GC-MS analysis is shown in Table 3. Evidently, the predominant component is ricinoleic acid methyl ester.

Table 3. Fatty acid composition of biodiesel (RAME)

\begin{tabular}{|c|c|c|}
\hline Fatty acid methyl ester & Structure & wt \% \\
\hline Methyl palmitate & C16:0 & 1.25 \\
\hline Methyl stearate & $\mathrm{C} 18: 0$ & 1.31 \\
\hline Methyl oleate & $\mathrm{C} 18: 1$ & 3.81 \\
\hline Methyl linoleate & $\mathrm{C} 18: 2$ & 5.27 \\
\hline Methyl linolenate & $\mathrm{C} 18: 3$ & 0.81 \\
\hline Methyl arachinidate & $\mathrm{C} 20: 0$ & 0.07 \\
\hline Methyl eicosenoate & $\mathrm{C} 20: 1$ & 0.38 \\
\hline Methyl ricinoleate & $\mathrm{C} 18: 1 \mathrm{OH}$ & 87.1 \\
\hline
\end{tabular}

\subsubsection{Fuel properties}

The physicochemical properties of biodiesel fuels have a remarkable impact on the combustion and emission characteristics. The variation in biodiesel composition owing to differences in feedstock is evidently accountable for the significant disparity observed in the performance and emission characteristics of engines operated using biodiesel fuels of different origin (Santos and Capareda, 2015). Table 4 shows the fuel properties of the biodiesel obtained at optimum condition in this study in comparison with ASTM D6751and EN 14214 standards specification.

Table 4. Fuel properties of synthesized RAME

\begin{tabular}{|c|c|c|c|c|c|}
\hline Property & Unit & Test method & Biodiesel & EN 14214 & ASTM D6751 \\
\hline Acid value & $\mathrm{mg} \mathrm{KOH} / \mathrm{g}$ & EN 14104 & 0.29 & $<0.50$ & $<0.50$ \\
\hline Flash point & ${ }^{\circ} \mathrm{C}$ & & 154 & $>120$ & $>130$ \\
\hline Heating value & $\mathrm{MJ} / \mathrm{kg}$ & EN 14213 & 36.72 & $>35$ & - \\
\hline $\begin{array}{l}\text { Kinematic } \\
\text { viscosity } \\
40^{\circ} \mathrm{C}\end{array}$ & $\mathrm{mm}^{2} / \mathrm{s}$ & ASTM D445 & 6.56 & $3.5-5.0$ & $1.9-6.0$ \\
\hline Specific gravity & & ASTM D445 & 0.862 & $0.86-0.90$ & $0.87-0.90$ \\
\hline Iodine value & $\mathrm{g} / 100 \mathrm{~g}$ & ASTM D445 & 26.22 & $<120$ & $<130$ \\
\hline Ash content & $\%$ & ASTM D445 & 0.09 & $<0.02$ & $<0.02$ \\
\hline $\begin{array}{l}\text { Moisture } \\
\text { content }\end{array}$ & $\% \mathrm{w} / \mathrm{w}$ & ASTM D445 & 0.071 & 0.05 & 0.05 \\
\hline Cetane number & & ASTM D613 & 55.2 & $44-56$ & $>47$ \\
\hline Cloud point & ${ }^{\circ} \mathrm{C}$ & ASTM D2500 & 3.7 & - & -3 to 12 \\
\hline $\begin{array}{l}\text { Cold filter } \\
\text { plugging point }\end{array}$ & ${ }^{\circ} \mathrm{C}$ & ASTM D2500 & -16.4 & -28 to 0 & $<0$ \\
\hline
\end{tabular}

Acid value is a measure of free fatty acids in the sample of castor oil used and biodiesel produced. The level acid value of feedstock oil may affect the level of biodiesel produced because of possible undesirable reactions like saponification which also affects the activity of catalyst $(\mathrm{KOH})$. The acid values of castor oil $6.74 \mathrm{mg} \mathrm{KOH} / \mathrm{g}$ is higher than that of biodiesel produced which is $0.29 \mathrm{mg}$ $\mathrm{KOH} / \mathrm{g}$. The acid value of biodiesel produced agrees with the $0.5 \mathrm{mg} \mathrm{KOH} / \mathrm{g}$ limit of both EN 14214 and ASTM D6751. 
Flash point is the temperature at which a fuel ignites when exposed to a flame due to the formation of a homogenous mixture of the fuel vapour and air above the fuel surface [18]. Flash point of biodiesel is important during storage to avoid explosion. EN 14214 stipulates flash point of above $120^{\circ} \mathrm{C}$ while ASTM D6751-02 value stands at $130^{\circ} \mathrm{C}$. The flash point measured for this study is $154^{\circ} \mathrm{C}$ which is higher than limit provided by both ASTM D6751 and EN 14214 and is therefore in conformity with specification. Negm et al. [12] reported a flash point of $151^{\circ} \mathrm{C}$. Moreso, flash point value of $202^{\circ} \mathrm{C}$ has been reported in the literature [18].

The heating value obtained from this study is $36.72 \mathrm{MJ} / \mathrm{kg}$, which is slightly higher than the $35 \mathrm{MJ} / \mathrm{kg}$ minimum specification of EN 14214 standards. The heating value of petroleum diesel is about 41.2 $\mathrm{MJ} / \mathrm{kg}$ which is somewhat higher than that for biodiesel in this work; this may be due to higher oxygen content of biodiesel.

Kinematic viscosity at $40^{\circ} \mathrm{C}$ of $21.76 \mathrm{~mm}^{2} / \mathrm{s}$ was obtained for the feedstock castor oil which on transesterification drastically reduced to $6.56 \mathrm{~mm}^{2} / \mathrm{s}$. The value for biodiesel is higher than the specification of both ASTM D6751 and EN 14214. Viscosity is essential for fuel atomization and distribution which is influenced by level of flowability. High viscosity of castor is the major rationale for not using it directly in fuel engines because it will not offer the desired lubrication needed at the injection pump rather giving rise to wear and leakage. Poor combustion and higher exhaust smoke can also result from high viscosity. Blending of castor biodiesel with either petro-diesel or biodiesel of much lower viscosity is therefore recommended.

Specific gravity has influence on atomization, fuel combustion efficiency and economy. With lower specific gravity, less mass is injected and atomization is easier and this increases fuel combustion efficiency and improve fuel economy of the engine. Specific gravity of 0.862 reported in this work is in consonance with EN 14214 standard of 0.860- 0.900. Specific gravity of the feedstock castor oil was 0.9560 and that of produced biodiesel was 0.862 , showing a decrease by $9.8 \%$.

The significance of iodine value is that it enables the determination of the degree of unsaturation of the biodiesel fuel and as such influences fuel oxidation tendency. Low iodine value is an indication of a better fuel. Iodine value greater than $50 \mathrm{~g} / 100 \mathrm{~g}$ may give rise to decrease engine service life. A higher degree of unsaturation is undesirable for fuels because its oxidation reaction which generally takes place at high temperatures during combustion may result in irreversible polymerization to plastic-like substances [18]. The iodine value of biodiesel produced in this study is $26.22 \mathrm{~g} / 100 \mathrm{~g}$ which represents a drastic reduction from that of feedstock castor oil which was $107.1 \mathrm{~g} / 100 \mathrm{~g}$. The synthesized biodiesel is in conformity with both ASTM D6751 and EN 14214 standards.

Ash content is the measure of non-combustible matter in the biodiesel and where it is high, injector tip plugging may result coupled with higher denser smoky deposits. Ash content of $0.09 \%$ was obtained from the biodiesel produced for this study and this is higher than $0.02 \%$ specifiction for biodiesel (ASTM D6751 and EN 14214).

Relatively higher moisture content of $0.071 \% \mathrm{w} / \mathrm{w}$ was obtained for the biodiesel of this work compared to $0.04 \% \mathrm{w} / \mathrm{w}$ obtained for the castor oil feedstock. Some $\mathrm{OH}^{-}$groups may have bonded to produce the excess water as well as certain levels of hydrolysis that may have suggestively occurred. High moisture content of fuel may trigger some undesirable side reactions which may use water to mask the energy of the fuel. The value obtained for this biodiesel is higher than the specifications of both ASTM D6751 and EN 14214 standards

Cetane number is a measure of the ignition quality of fuel and enables relating its suitability for use in compression ignition $(\mathrm{CI})$ engines. It represents the time delay between the start of injection and the point where the fuel ignites [36]. The Cetane number of biodiesels is relatively generally high when compared to that of petro-diesels. Literatures have reported cetane numbers of biodiesels between 45 
and 67 and that of petro-diesels 40 to 45 . Cetane number of the biodiesel sample of this work is 55.2, conforms to the ASTM D6751 and EN14214 specification standards.

Cloud point is the temperature at which small solid crystals are first visually observed as the fuel cools. Cloud point of $3.7^{\circ} \mathrm{C}$ obtained in this work agrees with the range of values permissible by ASTM D6751 standard.

Cold filter plugging point (CFPP) is the temperature at which a fuel will cause a fuel filter to plug due to fuel components which has began to crystallize or gelatinize. The CFPP obtained from optimal sample tested in this work is $-16.4^{\circ} \mathrm{C}$ and it is within the limit of ASTM D6751and EN 14214 standards.

\section{CONCLUSION}

Alkali-catalyzed methanolysis of castor (Ricinus communis) oil was carried out in a batch reactor to explore the effects of all five relevant process variables and establish their optimum values for maximum biodiesel yield. All factors were found to show significant influence on yield, with a maximum yield of $96 \%$ achieved at the reaction time of $60 \mathrm{~min}$, methanol to oil molar ratio of 12:1, reaction temperature of $65^{\circ} \mathrm{C}$, catalyst concentration of $1.5 \mathrm{wt} \%$ and stirring rate of $125 \mathrm{rpm}$. The obtained biodiesel at optimum condition was found to have properties that fall within the specifications of ASTM D6751 and EN 14214 standards, except for kinematic viscosity and moisture content. The castor biodiesel is therefore a very good candidate for blending with petro-diesel in furtherance of the B20 (20\% biodiesel and $80 \%$ petro-diesel) policy of the Nigerian oil and gas sector.

\section{REFERENCES}

[1] Bhagavatula A, Shah N, Honaker R. Estimating the pyrolysis kinetic parameters of coal, biomass, and their blends: A comparative study. Energy \& Fuels 2016; http://doi.10.1021/acs.energyfuels.5b00692.

[2] Bhuiya MMK, Rasul MG, Khan MMK, Ashwath N, Azad AK. Prospects of $2^{\text {nd }}$ generation biodiesel as a sustainable fuel - Part 1: Selection of feedstocks, oil extraction techniques and conversion technologies. Renewable and Sustainable Energy Reviews 2016; 55: 1109 - 1128.

[3] Nagesh Kumar MV, Gouri Shankar V, Ramya V, Bindu Priya P, Ramanjaneyulu AV, Seshu G, Vishnu Vardhan Reddy D. Enhancing castor (Ricinus communis L.) productivity through genetic improvement for Fusarium wilt resistance: a review. Industrial Crops and Products 2015; 67: 330 - 335.

[4] Ibeagha OA, Onwualu AP. Strategies for improving the value chain of castor as an industrial raw material in Nigeria. Agricultural Engineering International: CIGR Journal 2015; 17(3): 217 - 230.

[5] Ogunniyi DS. Castor oil: A vital industrial raw material. Bioresource Technology 2006; 97: 1086 1091.

[6] Mutlu H, Meier MAR. Castor oil as a renewable resource for the chemical industry. European Journal of Lipid Science and Technology 2010; 112: $10-30$.

[7] Meneghetti SMP, Meneghetti MR, Wolf CR, Silva EC, Lima GES, de Lira Silva L, Serra TM, Cauduro F, de Oliveira LG. Biodiesel from castor oil: A comparison of ethanolysis versus methanolysis. Energy \& Fuels 2006; 20: 2262 - 2265.

[8] Varma MN, Madras G. Synthesis of biodiesel from castor oil and Linseed oil in supercritical fluids. Industrial and Engineering Chemistry Research 2007; 46: $1-6$. 
[9] Pena R, Romero R, Martinez SL, Ramos MJ, Martinez A, Natividad R. Transesterification of castor oil: Effect of catalyst and co-solvent. Industrial and Engineering Chemistry Research 2009; 48: $1186-1189$.

[10] Sousa LL, Lucena IL, Fernandes FAN. Transesterification of castor oil: Effect of the acid value and neutralization of the oil with glycerol. Fuel Processing Technology 2010; 91: 194 - 196.

[11] Feng D, Jiang C, Yang J. Preparation of biodiesel from castor oil catalyzed by novel basic ionic liquid. Energy Technology 2013; 1: 135 - 138.

[12] Negm NA, Shaalam MA, El-Barouty GS, Mohamed MY. Preparation and evaluation of biodiesel from Egyptian castor oil and semi-treated industrial wastewater. Journal of the Taiwan Institute of Chemical Engineers 2016; 63: $151-156$.

[13] Silitonga AS, Masjuki HH, Ong HC, Yusaf T, Kusumo F, Mahlia TMI. Synthesis and optimization of Hevea brasiliensis and Ricinus communis as feedstock for biodiesel production: A comparative study. Industrial Crops and Products 2016; 85: 274-286.

[14] AOCS. Official and tentative methods. Chicago: American Oil Chemists' Society 1980.

[15] Cheng J, Li Y, He S, Shen W, Liu Y, Song Y. Reaction kinetics of transesterification between vegetable oil and methanol under super critical conditions. Energy Source Part A 2008; 30: 681-688.

[16] Yingying L., Houfang L, Wei J, Donsheng L, Shijie L, Bin L. biodiesel production from crude Jatropha curcas L. oil with trace acid catalyst. Chinese Journal of Chemcial Engineering 2012; 20(4): $740-746$.

[17] Rabelo SN, Ferraz VP, Oliveira LS, Franca AS. FTIR analysis for quantification of fatty acid methyl esters in biodiesel produced by microwave -assisted transesterification. International Journal of Environmental Science and Development 2015; 6(12): 964-969.

[18] Al-Hamamre Z, Yamin J. Parametric study of the alkali catalyzed transesterification of waste frying oil for biodiesel production. Energy Conversion and Management 2014; 79: 246-254.

[19] Kotwal MS, Niphadkar PS, Deshpande SS, Bokade VV, Joshi PN. Transesterification of sunflower oil catalyzed by flyash-based solid catalysts. Fuel 2009; 88: 1773-1778.

[20] Babajide O, Petrik L, Musyoka N, Amigun B, Ameer F. Use of coal fly ash as a catalyst in the production of biodiesel. Petroleum and Coal 2010; 52(4): 261-272.

[21] Musa IA. The effects of alcohol to oil molar ratios and the type of alcohol on biodiesel production using transesterification process. Egyptian Journal of Petroleum 2016; 25: 21-31.

[22] Yang J, Feng Y, Zeng T, Guo X, Li L, Hong R, Qui T. Synthesis of biodiesel via transesterification of tung oil catalyzed by new Bronsted acidic ionic liquid. Chemical Engineering Research and Design 2017; 117: 584-592.

[23] Nehdi IA, Sbihi HM, Mokbli S, Rashid U, AL-Resayes SI. Yucca aloifolia oil methyl esters. Industrial Crops and Products 2015; 69: 257-262. 
[24] Eevera T, Rajendran K, Saradha S. biodiesel production process optimization and characterization to assess the suitability of the product for varied environmental conditions. Renewable Energy 2009; 34: 762-765.

[25] Ejikeme PM, Anyaogu ID, Ejikeme CL, Nwafor NP, Egbuonu CAC, Ukogu K, Ibemesi JA. Catalysis in biodiesel production by transesterification processes - an insight. Journal of Chemistry 2010; 7(4): 1120-1132.

[26] Satyanarayana M, Muraleedharan C. A comparative study of vegetable oil methyl esters (biodiesels). Energy 2011; 36: 2129-2137.

[27] Deligiannis A, Anastopoulos G, Karavalakis G, Mattheou L, Karonis D, Zannikos F, Stournas S, Lois E. Castor (Ricinus communis L.) seed oil as an alternative feedstock for production of biodiesel. Environmental Science and Technology 2009; 1: 204-211.

[28] Ma F, Clements LD, Hanna MA. The effect of mixing on transesterification of beef tallow. Bioresource Technology 1999; 69(3): 289-293.

[29].Rashid U, Anwar F. Production of biodiesel through alkaline-catalyzed transesterification of rapeseed oil. Fuel 2008; 87(3): 265-273.

[30] Saez-Bastante J, Pinz S, Jimenez-Romero FJ, Luque de Castro MD, Priego-Capote F, Dorado MP. Synthesis of biodiesel from castor oil: Silent versus sonicated methylation and energy studies. Energy Conversion and Management 2015; 96: 561-567.

[31] Dai Y, Kao IH, Chen CC. Evaluating the optimum operating parameters of biodiesel production process from soybean oil using the $\mathrm{Li}_{2} \mathrm{TiO}_{3}$ catalyst. Journal of the Taiwan Institute of Chemical Engineers 2016, http://dx.doi.org/10.1016/j.jtice.2016.11.001.

[32] Roman-Figueroa C, Olivares-Carrillo P, Paneque M, Palacios-Nereo FJ, Quesada-Medina J. highyield production of biodiesel by non-catalytic supercritical methanol transesterification of crude castor oil (Ricinus communis). Energy 2016; 107: 165-171

[33] Amini Z, Ong HC, Harrison MD, Kusumo F, Mazaheri H, Ilham Z. biodiesel production by lipase-catalyzed transesterificationof Ocium basilicum L. (sweet basil) seed oil. Energy Conversion and Management 2017; 132: 82-90.

[34] Muppaneni T, Reddy HK, Ponnusamy S, Patil PD, Sun Y, Dailey P, Deng S. optimization of biodiesel production from palm oil under supercritical ethanol conditions using hexane as co-solvent: A response surface methodology. Fuel 2013; 107: 633-640.

[35] Santos BS, Capareda SC. A comparative study on the engine performance and exhaust emissions of biodiesel from various vegetable oils and animal fat. Journal of Sustainable Bioenergy Systems 2015; 5(3): 89-103.

[36] Mishra S, Anand K, Mehta PS. Predicting the cetane number of biodiesel fuels from their fatty acid methyl ester composition. Energy \& Fuels 2016; DOI: 10.1021/acs.energyfuels.6b01343. 